\title{
Maternal and perinatal outcomes in twin pregnancies conceived spontaneously and by assisted reproductive techniques: cross-sectional study
}

\author{
Diana Rashid ${ }^{1}$ and Shahla Alalaf ${ }^{2}$
}

${ }^{1}$ Maternity Teaching Hospital, Erbil City, Kurdistan Region, Iraq. ${ }^{2}$ Department of Obstetrics and Gynaecology, College of Medicine, Hawler Medical University, Erbil City, Kurdistan Region, Iraq. (Correspondence to: Shahla Alalaf: Shahla_alaf@yahoo.com; shahla.kareem@hmu.edu.krd).

\begin{abstract}
Background: Data vary on maternal and perinatal outcomes of twin pregnancies conceived through assisted reproductive technology compared with spontaneous conception.

Aims: This study compared maternal, perinatal and obstetric outcomes of dichorionic twin pregnancies conceived spontaneously with twin pregnancies conceived through assisted reproductive technology.

Methods: This was a cross-sectional study of dichorionic twins delivered at the Maternity Teaching Hospital, Erbil, Kurdistan Region, Iraq from 1 November 2016 to 31 December 2017. Twin pregnancies were classified into two groups: spontaneously conceived $(n=121)$ and conceived through assisted reproductive technology $(n=79)$. Maternal and perinatal outcomes were compared between the two groups. The chi-squared test was used to compare categorical variables and the Student $t$-test to compare means. Logistic regression analysis was used to assess factors associated with admission to the neonatal intensive care unit.

Results: Pregnancy-induced hypertension, gestational diabetes and preterm rupture of membranes were more common in mothers in the assisted reproductive technology group $(P<0.05)$. Preterm birth, low neonatal birth weight and congenital malformation were also more common in the assisted reproductive technology group $(P<0.001)$. Gestational age $<33$ weeks and conception through assisted reproductive technology were significantly associated with admission to the neonatal intensive care unit for both twins.
\end{abstract}

Conclusion: Studies are needed to assess the reasons for the differences in perinatal and maternal outcomes between twin pregnancies conceived spontaneously and through assisted reproductive technology.

Keywords: assisted reproductive techniques, twin pregnancy, perinatal outcomes, maternal outcomes, Iraq

Citation: Rashid D; Alalaf S. Maternal and perinatal outcomes in twin pregnancies conceived spontaneously and by assisted reproductive techniques: cross-sectional study. East Mediterr Health J. 2020; 26(10): 1285-1293. https://doi.org/10.26719/emhj.20.041

Received: 17/07/18; accepted: 22/10/19

Copyright (c) World Health Organization (WHO) 2020. Open Access. Some rights reserved. This work is available under the CC BY-NC-SA 3.0 IGO

license (https://creativecommons.org/licenses/by-nc-sa/3.o/igo)

\section{Introduction}

Assisted reproductive technology, including induced ovulation, has become a widespread choice for the treatment of human infertility in recent decades. A consequence of assisted reproductive technology has been the progressive rise in the incidence of twin pregnancies (1). Twin pregnancies are associated with an increased risk of maternal and neonatal morbidity and mortality compared with singleton pregnancies (2-4). Different findings have been reported for neonatal and maternal outcomes, and these variations may be a result of differences in the studied populations and/or in the management of twin pregnancy. Furthermore, data are conflicting on pregnancy outcomes for dichorionic twins (each with a separate placenta and amniotic sac) conceived by assisted reproductive technology compared with those naturally conceived. Some research has suggested that perinatal mortality was significantly lower in twin pregnancy from assisted conception compared with spontaneously conceived twin pregnancy $(2,3,5)$. An increase in antenatal complications has been reported for assisted-concep- tion twin pregnancies, but only limited effects on the morbidity and mortality of an individual pregnancy (5). In contrast, other research has shown an increased risk of adverse neonatal outcomes and increased rate of caesarean delivery, especially in twins conceived by assisted reproductive technology, compared with twins conceived spontaneously. However, there were no significant differences in the incidences of perinatal death or congenital malformations (5-7).

Given these varying findings, we aimed to compare maternal, perinatal and obstetric outcomes in dichorionic twin pregnancies conceived spontaneously and through assisted reproductive technology in Erbil city, Kurdistan region, Iraq.

\section{Methods}

\section{Study design and sample}

This was a cross-sectional study of twins born in the Maternity Teaching Hospital, Erbil City, Kurdistan region, Iraq, from 1 November 2016 to 31 December 2017. The 
Maternity Teaching Hospital is the only public maternity hospital in the city in which women of different backgrounds give birth, making our sample representative $(8,9)$.

\section{Inclusion and exclusion criteria}

Inclusion criteria were: diachronic diamniotic twin delivery, gestational age $>24$ weeks and birth weight of each twin $\geq 500$ g. Exclusion criteria were: intrauterine foetal death, higher-order multiple pregnancies, deliveries complicated by early vanishing foetuses, twin pregnancies reduced to singleton, and triplet pregnancy reduced to twin pregnancy.

\section{Data collection and study variables}

Twin births were identified in the outpatient clinic when the pregnant women were admitted to the hospital in order to prepare them for caesarean section or to labour ward for natural labour. They were classified into two groups: conceived through assisted reproductive technology (induction of ovulation and assisted reproductive techniques) and conceived spontaneously.

Pregnant women were followed up from the time of admission and up to 40 days postpartum. Maternal information was recorded in a questionnaire designed for the study which included data on: maternal age, parity, pregnancy complications (pregnancy-induced hypertension, preeclampsia, gestational diabetes mellitus, preterm premature rupture of membranes, antepartum haemorrhage and anaemia in pregnancy). During delivery, data on mode of delivery (vaginal or caesarean) were recorded. After delivery, the following data on the newborn twins were recorded: birth weight, Apgar score, congenital abnormalities, respiratory distress syndrome, admission to the neonatal intensive care unit, and survival in the first week of life. Maternal postpartum complications were also recorded including: postpartum haemorrhage, blood transfusion, postpartum anaemia after one week of delivery and deep vein thrombosis.

Gestational age for twin pregnancies from assisted reproductive technology was calculated from the date of embryo transfer. For spontaneous twin pregnancies, gestational age was calculated according to first trimester ultrasound estimations (10).

Pregnancy-induced hypertension was defined as blood pressure $>140 / 90 \mathrm{mmHg}$ measured on two occasions 4-6 hours apart after 20 weeks gestation without proteinuria (11). Diagnosis of gestational diabetes mellitus was based on the guidelines of the National Institute for Health and Care Excellence (NICE) - fasting plasma glucose $\geq 5.6$ $\mathrm{mmol} / \mathrm{L}$, or 2-hour plasma glucose $\geq 7.8 \mathrm{mmol} / \mathrm{L}$ (12). Antepartum haemorrhage was defined as any uterine bleeding episode after 24 weeks gestation (13). Preterm premature rupture of membranes was defined as rupture of membranes with amniotic fluid without uterine activity (14). Primary or secondary postpartum haemorrhage was defined as the loss of $\geq 500 \mathrm{~mL}$ of blood from the genital tract in a 24 -hour period for up to 12 weeks of birth (15). Blood transfusion was performed during management of massive antepartum haemorrhage and/or postpartum haemorrhage from blood loss $>1000 \mathrm{~mL}$ and/or signs of clinical shock (16). Anaemia in pregnancy was defined as a haemoglobin concentration $<11 \mathrm{~g} / \mathrm{L}$ in venous blood (17). Postpartum anaemia was defined by haemoglobin $<11 \mathrm{~g} / \mathrm{L}$ at 1 week postpartum (18). Diagnosis of deep vein thrombosis was based on guidelines of the Royal College of Obstetricians and Gynaecologists - patient presenting with pain, redness and swelling of left leg. Compression ultrasound confirmed the diagnosis (19).

All neonates were evaluated by an expert neonatologist in the week following birth. Perinatal outcomes included (preterm delivery, admission to the neonatal intensive care unit, low birth weight, congenital malformation, respiratory distress syndrome and stillbirth).

Extremely preterm labour was defined as $<28$ weeks of gestation, very preterm ( 28 to $<32$ weeks) and late preterm (32 to < 37 weeks) gestation (20). Birth weight was categorized as: extremely low birth weight $=\leq 999 \mathrm{~g}$; very low birth weight $=1000$ to $1499 \mathrm{~g}$, low birth weight $=1500$ to $2499 \mathrm{~g}$ and normal birth weight $=\geq 2500 \mathrm{~g}(21)$. The Apgar score was classified as low (0-3), moderately abnormal (4-6) and reassuring (7-10) (22).

Respiratory distress syndrome was defined as the presence of a characteristic radiographic finding and the need for oxygen for 24 hours (23) in new-borns with tachypnoea, nasal flaring, grunting, intercostal or subcostal retractions and cyanosis (24). Neonatal sepsis was defined as the presence of signs and symptoms of infection with or without accompanying bacteraemia in the first week of life that encompasses various systemic infections of the new-born such as septicaemia, meningitis, pneumonia, arthritis, osteomyelitis, and urinary tract infections (25).

\section{Care of mothers and babies}

Our institutional protocol for the management of highrisk pregnant women in labour includes teamwork and good communication between health care providers, and response to obstetric emergencies in real time to ensure the perinatal and obstetric safety of twin pregnancies in labour. The clinical management of the pregnant women in both groups was provided by a professional obstetrician and certified nurses and midwives. Vaginal delivery and caesarean section were conducted in a well-equipped labour room and operating room. Both groups were followed up and managed during labour by the same team.

\section{Statistical analysis}

Data were analysed using SPSS, version 22. The chisquared test was used to compare proportions between women with spontaneous and assisted reproductive technology pregnancies according to the variables studied. The Fisher exact test was used when the expected count of more than $20 \%$ of the cells of the table was $<5$. The Student t-test was used to compare means. Variables found significant with the chi-squared test were included 
in a logistic regression analysis. The Cramér V was calculated to assess the strength of association between categorical variables (effect size). A $P$-value $\leq 0.05$ was considered statistically significant.

\section{Ethical considerations}

The Ethics and Scientific Committee of the Kurdistan Board of Medical Specialties approved this study. Written informed consent was obtained from each woman who agreed to participate in the study at the time of the first interview. All participants were assured that their information would be kept confidential and would be used for research purposes only. All interviews were carried out in accordance with the ethical standards of the institutional research committee.

\section{Results}

In total, 247 women with twin pregnancies were interviewed and 7 women were excluded - 5 women for not meeting the inclusion criteria and two women declined to participate. Of the women with twin pregnancies who participated in the study, 121 were spontaneous twin pregnancies and 79 resulted from assisted reproductive technology. Table 1 shows the characters of the women according to whether the twin pregnancy was spontaneous or through assisted reproductive technology.

Cramér V (effect size) showed moderately strong and significant association between both pregnancy-induced hypertension $(V=0.478, \quad P<0.001)$ and gestational diabetes mellitus $(V=0.366, P<0.001)$ and conception through assisted reproductive technology compared with spontaneous conception (Table 2).

Cramér $\mathrm{V}$ showed a moderately strong association between preterm birth, low birth weight and depressed Apgar scores and both assisted reproductive technology and spontaneous pregnancy ( $V$ ranging from 0.304 to $0.500 ;$ Table 3). Significant differences were found between the groups for gestational age, birth weight and Apgar score in first and second twins in favour of spontaneous twins $(P<0.001)$.

A significantly greater proportion of secondborn twins had congenital anomalies in the assisted reproductive technology group than in the spontaneous group $(P=0.036)$, although the strength of the association was weak $(V=0.158)$. For both first- and second-born twins, there was a moderately strong association with admission to the neonatal intensive care unit in both the assisted reproductive technology group and the spontaneous group $(V=0.312$ for first-born and $V=0.305$ for second-born, respectively). In addition, a significantly greater proportion of both first- and second-born twins in the assisted reproductive technology group were admitted to the neonatal intensive care unit than in the spontaneous group $(P<0.001$; Table 4$)$.

In logistic regression analysis of the factors associated with admission to the neonatal intensive care unit for the first-born twin (Table 5), gestational age < 33 weeks $(\mathrm{OR}=95.24,95 \mathrm{CI}: 20.81-435.87)$ and being in the assisted reproductive technology group compared with the spontaneous group $(\mathrm{OR}=4.94,95 \% \mathrm{CI}$ : 1.68-14.52) were both statistically significant risks. In logistic regression analysis of the factors associated with admission to

\begin{tabular}{|c|c|c|c|c|}
\hline \multirow[t]{2}{*}{ Characteristic } & $\begin{array}{l}\text { Spontaneous } \\
(n=121)\end{array}$ & $\begin{array}{l}\text { Assisted reproductive } \\
\text { technology } \\
(n=79)\end{array}$ & $\begin{array}{c}\text { Total } \\
(n=200)\end{array}$ & $P$-value ${ }^{a}$ \\
\hline & No. (\%) & No. (\%) & No. (\%) & \\
\hline Age (years) & & & & $<0.001$ \\
\hline$<25$ & $32(26.4)$ & $1(1.3)$ & $33(16.5)$ & \\
\hline $25-29$ & $21(17.4)$ & $11(13.9)$ & $32(16.0)$ & \\
\hline $30-34$ & $21(17.4)$ & $19(24.1)$ & $40(20.0)$ & \\
\hline $35-39$ & $19(15.7)$ & $32(40.5)$ & $51(25.5)$ & \\
\hline$\geq 40$ & $28(23.1)$ & $16(20.3)$ & $44(22.0)$ & \\
\hline Mean (SD) & $31.18(8.58)$ & $35.41(4.84)$ & & $<0.001^{\mathrm{b}}$ \\
\hline Parity & & & & $<0.001$ \\
\hline Primigravida & $24(19.8)$ & $35(44.3)$ & $59(29.5)$ & \\
\hline Multiparous & $71(58.7)$ & $43(54.4)$ & $114(57.0)$ & \\
\hline Grand multiparous & $26(21.5)$ & $1(1.3)$ & $27(13.5)$ & \\
\hline Mean (SD) & $2.61(2.42)$ & $0.84(0.97)$ & & $<0.001^{\mathrm{b}}$ \\
\hline Family history of twins & & & & $<0.001$ \\
\hline Yes & $59(48.8)$ & $0(0.0)$ & $59(29.5)$ & \\
\hline No & $62(51.2)$ & $79(100.0)$ & $141(70.5)$ & \\
\hline
\end{tabular}


Table 2 Maternal antepartum and postpartum complications according to whether the twin pregnancy was spontaneous or through assisted reproductive technology

\begin{tabular}{|c|c|c|c|c|}
\hline \multirow[t]{2}{*}{ Complication } & $\begin{array}{l}\text { Spontaneous } \\
(n=121)\end{array}$ & $\begin{array}{l}\text { Assisted reproductive } \\
\text { technology } \\
(\mathbf{n}=\mathbf{7 9})\end{array}$ & Cramér V & P-value ${ }^{a}$ \\
\hline & No. (\%) & No. (\%) & & \\
\hline Antepartum haemorrhage & $12(9.9)$ & $15(19)$ & 0.130 & 0.06 \\
\hline Pregnancy-induced hypertension & $3(2.5)$ & $31(39.2)$ & 0.478 & $<0.001$ \\
\hline Gestational diabetes mellitus & $1(0.8)$ & $18(22.8)$ & 0.366 & $<0.001$ \\
\hline Preterm premature rupture of membranes & $28(23.1)$ & $31(39.2)$ & 0.173 & 0.015 \\
\hline Anaemia in pregnancy & $10(8.3)$ & $3(3.8)$ & 0.089 & 0.210 \\
\hline Postpartum haemorrhage & $21(17.4)$ & $22(27.8)$ & 0.125 & 0.077 \\
\hline Blood transfusion & $26(21.5)$ & $24(30.4)$ & 0.100 & 0.156 \\
\hline Postpartum anaemia & $36(29.8)$ & $27(34.2)$ & 0.047 & 0.510 \\
\hline Deep vein thrombosis & $1(0.8)$ & $\mathrm{o}(0)$ & 0.057 & $0.999^{\mathrm{b}}$ \\
\hline
\end{tabular}

${ }^{a}$ Chi-squared test.

${ }^{b}$ Fisher exact test.

Table 3 Conditions at birth for each twin according to whether the twin pregnancy was spontaneous or through assisted reproductive technology

\begin{tabular}{|c|c|c|c|c|c|}
\hline \multirow[t]{2}{*}{ Variable } & \multirow{2}{*}{ 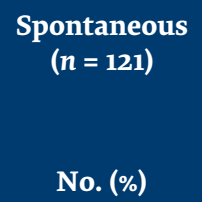 } & \multirow{2}{*}{$\begin{array}{c}\text { Assisted } \\
\text { reproductive } \\
\text { technology } \\
(\mathbf{n}=79) \\
\text { No. (\%) }\end{array}$} & \multirow{2}{*}{$\begin{array}{c}\text { Total } \\
(n=200) \\
\text { No. }(\%)\end{array}$} & \multirow[t]{2}{*}{ Cramér V } & \multirow[t]{2}{*}{$P$-value ${ }^{\mathrm{a}}$} \\
\hline & & & & & \\
\hline \multicolumn{6}{|l|}{ Gestational age twin 1} \\
\hline Extremely preterm & $15(12.4)$ & $4(5.1)$ & $19(9.5)$ & 0.471 & $<0.001$ \\
\hline Very preterm & $31(25.6)$ & $57(72.2)$ & $88(44.0)$ & & \\
\hline Late preterm & $62(51.2)$ & $18(22.8)$ & $80(40.0)$ & & \\
\hline Term & $13(10.7)$ & $0(0.0)$ & $13(6.5)$ & & \\
\hline \multicolumn{6}{|l|}{ Gestational age twin 2} \\
\hline Extremely preterm & $15(12.4)$ & $5(6.3)$ & $20(10.0)$ & 0.500 & $<0.001$ \\
\hline Very preterm & $33(27.3)$ & $61(77.2)$ & $94(47.0)$ & & \\
\hline Late preterm & $60(49.6)$ & $13(16.5)$ & $73(36.5)$ & & \\
\hline Term & $13(10.7)$ & $0(0.0)$ & $13(6.5)$ & & \\
\hline \multicolumn{6}{|l|}{ Birth weight twin 1} \\
\hline Extremely low birth weight & $19(15.7)$ & $6(7.6)$ & $25(12.5)$ & 0.420 & $<0.001$ \\
\hline Very low birth weight & $4(3.3)$ & $8(10.1)$ & $12(6.0)$ & & \\
\hline Low birth weight & $38(31.4)$ & $53(67.1)$ & $91(45.5)$ & & \\
\hline Normal & $60(49.6)$ & $12(15.2)$ & $72(36.0)$ & & \\
\hline \multicolumn{6}{|l|}{ Birth weight twin 2} \\
\hline Extremely low birth weight & $18(14.9)$ & $9(11.4)$ & $27(13.5)$ & 0.374 & $<0.001$ \\
\hline Very low birth weight & $6(5.0)$ & $9(11.4)$ & $15(7.5)$ & & \\
\hline Low birth weight & $44(36.4)$ & $52(65.8)$ & $96(48.0)$ & & \\
\hline Normal & $53(43.8)$ & $9(11.4)$ & $62(31.0)$ & & \\
\hline \multicolumn{6}{|l|}{ Apgar at 1 min twin 1} \\
\hline Low & $16(13.2)$ & $3(3.8)$ & $19(9.5)$ & 0.500 & $<0.001$ \\
\hline Moderately abnormal & $41(33.9)$ & $67(84.8)$ & $108(54.0)$ & & \\
\hline Reassuring & $64(52.9)$ & $9(11.4)$ & $73(36.5)$ & & \\
\hline \multicolumn{6}{|l|}{ Apgar at 1 min twin 2} \\
\hline Low & $18(14.9)$ & $12(15.2)$ & $30(15.0)$ & 0.417 & $<0.001$ \\
\hline Moderately abnormal & $46(38.0)$ & $60(75.9)$ & $106(53.0)$ & & \\
\hline Reassuring & $57(47.1)$ & $7(8.9)$ & $64(32.0)$ & & \\
\hline
\end{tabular}


Table 3 Conditions at birth for each twin according to whether the twin pregnancy was spontaneous or through assisted reproductive technology (Concluded)

$\begin{array}{lccc}\text { Variable } & \begin{array}{c}\text { Spontaneous } \\ (\mathbf{n = 1 2 1})\end{array} & \begin{array}{c}\text { Assisted } \\ \text { reproductive } \\ \text { technology } \\ (\mathbf{n}=\mathbf{7 9})\end{array} & \begin{array}{c}\text { Total } \\ (\mathbf{n}=\mathbf{2 0 0})\end{array} \\ & \text { No. (\%) } & \text { No. (\%) } & \text { No. (\%) }\end{array}$

min: minute.

${ }^{a}$ Chi-sqaured test.

the neonatal intensive care unit for the second-born twin (Table 6), gestational age $<33$ weeks ( $O R=40.35$, 95\% CI: 12.75-127.70) and being in the assisted reproductive technology group $(\mathrm{OR}=4.94$, 95\% CI: 1.68 14.52) were both statistically significant risks.

\section{Discussion}

Assisted reproductive technologies have been widely recommended all over the world as successful and common treatments following the increased rate of infertility $(26,27)$. As a consequence, rates of twin pregnancies are increased in assisted reproductive treatment cycles (28). In our study, the rates of maternal complications, such as pregnancy-induced hypertension, gestational diabetes mellitus and preterm premature rupture of membranes, were significantly higher in the assisted reproductive technology group compared with the spontaneous group. In contrast, for other complication there was no any difference between the two groups. A 2016 study reported that multiple pregnancies after assisted reproductive techniques are the single most likely explanation for the increased rate of gestational hypertension and preeclampsia in mothers who had undergone assisted reproductive treatment (29). The authors suggested that a policy to minimize twin pregnancies after these techniques may reduce the increased risk of gestational hypertension and preeclampsia (29). Another study also concluded that poor outcomes (preeclampsia, gestational diabetes and preterm labour) were significantly more common in mothers of twins conceived by assisted reproductive techniques (7). The authors advised that couples should be aware of these potential risks before choosing assisted reproductive techniques (7). However, other research

\begin{tabular}{|c|c|c|c|c|c|}
\hline \multirow[t]{2}{*}{ Outcome } & $\begin{array}{l}\text { Spontaneous } \\
(n=121)\end{array}$ & $\begin{array}{l}\text { Assisted reproductive } \\
\text { technology } \\
(\mathbf{n}=79)\end{array}$ & $\begin{array}{c}\text { Total } \\
(n=200)\end{array}$ & Cramér V & P-value ${ }^{a}$ \\
\hline & No. (\%) & No. (\%) & No. $(\%)$ & & \\
\hline Congenital malformations twin 1 & $3(2.5)$ & $4(5.1)$ & $7(3.5)$ & 0.069 & $0.438^{b}$ \\
\hline Congenital malformations twin 2 & $1(0.8)$ & $5(6.3)$ & $6(3.0)$ & 0.158 & $0.036^{\mathrm{b}}$ \\
\hline NCIU admission twin 1 & $57(47.1)$ & $62(78.5)$ & $119(59.5)$ & 0.312 & $<0.001$ \\
\hline NCIU admission twin 2 & $58(47.9)$ & $62(78.5)$ & $120(60.0)$ & 0.305 & $<0.001$ \\
\hline Neonatal sepsis twin 1 & $25(20.7)$ & $12(15.2)$ & $37(18.5)$ & 0.069 & 0.33 \\
\hline Neonatal sepsis twin 2 & $26(21.5)$ & $21(26.6)$ & $47(23.5)$ & 0.059 & 0.406 \\
\hline Respiratory distress syndrome twin 1 & $42(34.7)$ & $33(41.8)$ & $75(37.5)$ & 0.071 & 0.313 \\
\hline Respiratory distress syndrome twin 2 & $45(37.2)$ & $40(50.6)$ & $85(42.5)$ & 0.133 & 0.06 \\
\hline Survival twin 1 & $92(76.0)$ & $64(81.0)$ & $156(78.0)$ & 0.059 & 0.406 \\
\hline Survival twin 2 & $91(75.2)$ & $51(64.6)$ & $142(71.0)$ & 0.115 & 0.105 \\
\hline
\end{tabular}

NCIU: neonatal intensive care unit.

${ }^{a}$ Chi-squared test.

${ }^{b}$ Fisher exact test. 


\begin{tabular}{|c|c|c|c|}
\hline Variable & B & P-value & OR $(95 \% \mathrm{CI})$ \\
\hline Pregnancy-induced hypertension & 0.021 & 0.975 & $1.02(0.28-3.71)$ \\
\hline \multicolumn{4}{|l|}{ Gestational age (weeks) } \\
\hline$\geq 33$ (reference) & & & 1.00 \\
\hline$<33$ & 4.556 & $<0.001$ & $95.24(20.81-435.87)$ \\
\hline \multicolumn{4}{|l|}{ Twin pregnancy group } \\
\hline Spontaneous (reference) & & & 1.00 \\
\hline Assisted reproduction technology & 1.599 & 0.004 & $4.94(1.68-14.52)$ \\
\hline Antepartum haemorrhage & 1.370 & 0.226 & $3.93(0.42-36.14)$ \\
\hline
\end{tabular}

OR: odds ratio; CI: confidence interval.

concluded that maternal complications, such as preterm premature ruptures of membranes, pregnancy-induced hypertension and gestational diabetes, were not significantly different between women with assisted reproduction versus spontaneous conception (30). Findings also differ on the other maternal complications with assisted reproduction versus spontaneous conception $(31,32)$.

The differences in the maternal outcomes in the literature may be because of differences in sample sizes for both assisted reproductive technique and spontaneous twins groups, the settings where the research was conducted and the methods used for assisted reproduction techniques.

Poor neonatal outcomes were markedly higher in the assisted reproductive technology group than the spontaneous group in our study. This was in agreement with a prospective follow-up study that reported that assisted reproductive technology twin pregnancies were at greater risk of low birth weight, preterm birth, congenital anomalies, neonatal respiratory distress syndrome and perinatal mortality (33). A review of maternal and neonatal records found that twins conceived with assisted reproductive technologies compared with twins conceived spontaneously: had a lower mean birth weight for both twins; more neonates weighed < 1500 g; more had Apgar scores $<7$ at 5 minutes; more were admitted to the intensive care unit; and more second twins died in the neonatal period. (34).

Gestational age $<33$ weeks in both twins and conception through assisted reproductive technology were significantly associated with admission to the neonatal intensive care unit for both twins in our study. This finding concurs with other research (33) but not with another study that concluded that perinatal and neonatal morbidity, gestational age at delivery and birth weight were not affected by assisted reproductive techniques compared with spontaneous conception (30). Twin pregnancies conceived via assisted reproductive techniques are at greater risk of poorer outcomes than spontaneous twin pregnancies and this may be related to the type of conception and negative maternal characteristics, for example being subfertile and undergoing infertility treatment.

A strength of our study was that it examined pregnancies in a busy hospital with facilities to manage women with high- risk deliveries, including twin pregnancies. Another strength is that both groups were similarly managed during labour, including both vaginal and caesarean section deliveries. A limitation of our study is that we did not examine the effect of factors such as socioeconomic status, educational level, food intake and lifestyle on the perinatal outcomes of the twin pregnancies. These factors should be examined in future studies, as well as the reasons for the differences in perinatal and maternal outcomes between twin pregnancies conceived spontaneously and through assisted reproductive technology, including the techniques used in assisted reproductive technology.

Our study supports the findings that assisted reproductive techniques have poorer perinatal and maternal outcomes. The reasons for the worse outcomes in comparison to spontaneous twins are not known and

\begin{tabular}{|c|c|c|c|}
\hline Variable & B & P-value & OR (95\% CI) \\
\hline Pregnancy-induced hypertension & 0.127 & 0.841 & $1.13(0.32-3.92)$ \\
\hline \multicolumn{4}{|l|}{ Gestational age (weeks) } \\
\hline$\geq 33$ (reference) & & & 1.00 \\
\hline$<33$ & 3.698 & $<0.001$ & $40.35(12.75-127.70)$ \\
\hline \multicolumn{4}{|l|}{ Twin pregnancy group } \\
\hline Spontaneous (reference) & & & 1.00 \\
\hline Assisted reproduction technology & 1.449 & 0.005 & $4.26(1.54-11.77)$ \\
\hline Antepartum haemorrhage & 0.635 & 0.454 & $1.88(0.35-9.95)$ \\
\hline
\end{tabular}

OR: odds ratio; CI: confidence interval. 
warrant further investigation in a multicentre study with a large sample size, using the same design and follow- up including same treatment protocols for assisted reproduction techniques.

\section{Acknowledgement}

We thank all the participants and Charles Allan from Edanz Group for editing a draft of this manuscript.

Funding: None.

Competing interests: None declared.

\section{Résultats maternels et périnatals de grossesses gémellaires spontanées et issues de techniques de procréation assistée : étude transversale \\ Résumé}

Contexte : Les données concernant les résultats maternels et périnatals des grossesses gémellaires varient selon qu'elles ont été obtenues par des techniques de procréation assistée ou spontanément.

Objectifs : L'étude a permis de comparer les résultats maternels, périnatals et obstétricaux de grossesses gémellaires dichorioniques obtenues spontanément par rapport à des grossesses issues de techniques de procréation assistée.

Méthodes: La présente étude portait sur des jumeaux dichorioniques nés à la maternité de l'hôpital universitaire d'Erbil (région du Kurdistan, Iraq) entre le $1^{\text {er }}$ novembre 2016 et le 31 décembre 2017. Les grossesses gémellaires ont été classées en deux groupes : grossesses spontanées $(n=121)$ et grossesses issues de techniques de procréation assistée $(n=79)$. On a comparé les résultats maternels et périnatals entre les deux groupes. Le test du chi carré a été utilisé pour comparer les variables catégorielles tandis qu'on a recouru au test te Student pour comparer les moyennes. L'analyse de régression logistique a été utilisée pour évaluer les facteurs associés à l'admission en unité de soins intensifs néonatals.

Résultats : L'hypertension gravidique, le diabète gestationnel et les ruptures prématurées de membranes étaient plus fréquentes chez les mères appartenant au groupe des grossesses issues de techniques de procréation assistée $(p<0,05)$. Les naissances prématurées, le faible poids à la naissance et les malformations congénitales étaient également plus courants dans le groupe des grossesses issues de techniques de procréation assistée $(p<0,001)$. Un âge gestationnel inférieur à 33 semaines et une conception par procréation assistée étaient fortement associés à l'admission des deux jumeaux en unité de soins intensifs néonatals.

Conclusion: Il est nécessaire de mener des études pour évaluer les causes des différences entre les résultats périnatals et maternels des grossesses gémellaires spontanées et des grossesses obtenues par des techniques de procréation assistée.

$$
\begin{aligned}
& \text { مقارنة مخرجات فترة الأمومة والفترة المحيطة بالو لادة فيا يتعلق بحالات حمل التواتئ التمات التلقائية بحالات حمل التوائم }
\end{aligned}
$$

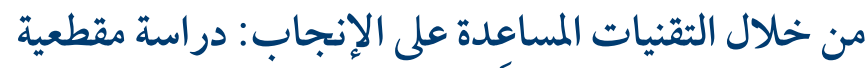

$$
\begin{aligned}
& \text { ديانا رشيد، شهاء العلاف } \\
& \text { الخلاصة } \\
& \text { الخلفية: تتفاوت بيانات النتائج في فترة الأمومة و الفترة المحيطة بالو لادة فيما يتعلق بحالات حمل التوائم من خلال التقنيات المساعِة على الإنجاب }
\end{aligned}
$$

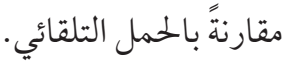

$$
\begin{aligned}
& \text { الأهداف: هدفت هذه الدر اسة إلى مقارنة مخرجات حالات حمل التو ائم ثنائية المشياء التلقائية فترة الأمومة و الفترة المحيطة بالو لادة ومرحلة التوليد }
\end{aligned}
$$

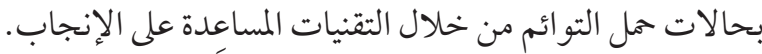

$$
\begin{aligned}
& \text { طرق البحث: كانت هذه دراسة مقطعية لحالات ولادة توائم ثنائية المشيماء في مستشفى الولادة التعليمي في أربيل بإقليم كردستان العراق خلال }
\end{aligned}
$$

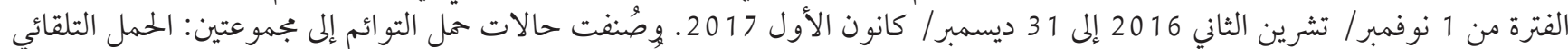

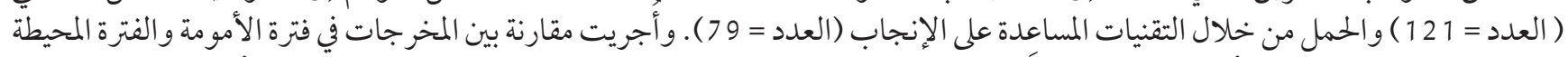

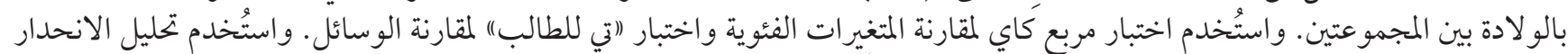

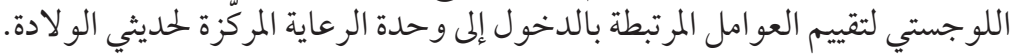

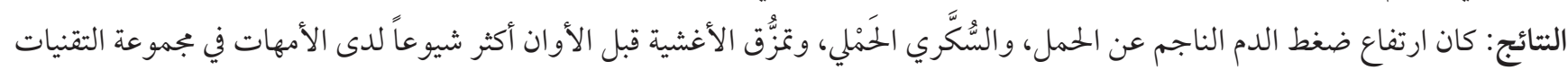




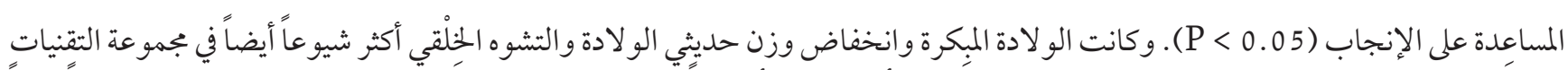

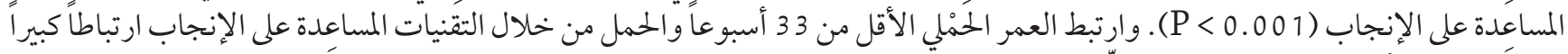

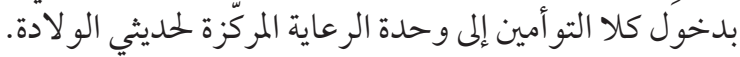

الاستنتاجات: ثََّّة حاجة إلى دراسات لتقييم أسباب اختابلاف النتائج في الفترة المحيطة بالو لادة وفترة الأمومة بين حالات التات حمل التوائم التلقائية

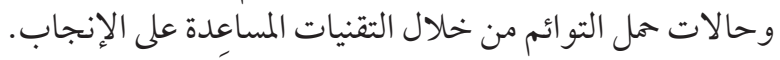

\section{References}

1. Pyrbot JE, Agarwal M. Twin pregnancy - maternal and fetal complications its association with mode of delivery: a study in a tertiary center. Int J Reprod Contracept Obstet Gynecol. 2017;6(11):5089-94. http://doi.org/10.18203/2320-1770.ijrcog20175030

2. Bhandari S, Agrawal P, Ganguly I, Singh A, Gupta N. Perinatal outcome in assisted reproductive pregnancies: comparative analysis of reduced versus unreduced gestation. Int J Reprod Med. 2016;2016:7504609. http://doi.org/10.1155/2016/7504609

3. Hunter A, Breathnach, M, Mcauliffe M, Geary P, Daly S, Malone D. Comparison of outcomes of twins conceived spontaneously and by artificial reproductive therapy. J Matern-Fetal Neonatal Med. 2014;27(5):458-62. https://doi.org/10.3109/14767058.2013.818 653

4. Gillet E, Martens E, Martens G, Cammu H. Prelabour caesarean section following IVF/ICSI in older-term nulliparous women: too precious to push? J Pregnancy. 2011;2011: 362518. https://doi.org/10.3109/14767058.2013.81865310.1155/2011/362518

5. Qin B, Wang H, Sheng X, Xie Q, Gao S. Assisted reproductive technology and risk of adverse obstetric outcomes in dichorionic twin pregnancies: a systematic review and meta-analysis. Fertil Steril. 2016;105(5):1180-92. https://doi.org/10.1016/j.fertni stert.2015.12.131

6. Fedder J, Loft A, Parner T, Rasmussen S, Pinborg A. Neonatal outcome and congenital malformations in children born after ICSI with testicular or epididymal sperm: a controlled national cohort study. Hum Reprod. 2013;28:230-40. https://doi.org/10.1093/ humrep/des377

7. Pourali, Ayati S, Jelodar S, Zarifian A, Andalibi S. Obstetrics and perinatal outcomes of dichorionic twin pregnancy following ART compared with spontaneous pregnancy. Int J Reprod Biomed. 2016;14(5):317-22.

8. Population projections by governorates, social origin for the year 2011. Baghdad: Iraq Ministry of Planning/Central Statistical Organization; 2011 (http://www.cosit.gov.iq/AAS13/population/pop(13).htm, accessed 11 April 2020).

9. Akrawi V, Al-Hadithi T, Al-Tawil N . Major determinants of maternal near-miss and mortality at the Maternity Teaching Hospital, Erbil city, Iraq. Oman Med J. 2017;32(5):386-95. https://doi.org/10.5001/omj.2017.74

10. Multiple pregnancies: antenatal care for twin and triplet pregnancies. Clinical guideline [CG129]. London: National Institute for Health and Care Excellence (NICE); 2011.

11. Hypertension in pregnancy: diagnosis and management. Clinical guideline [CG107]. London: National Institute for Health and Care Excellence (NICE); 2011.

12. Diabetes in pregnancy: management from preconception to the postnatal period. NICE guideline [NG3]. London: National Institute for Health and Care Excellence (NICE); 2015.

13. Antepartum haemorrhage (green-top guideline No. 63). London: Royal College of Obstetricians and Gynaecologists; 2011.

14. Preterm labour and birth. NICE guideline [NG25]. London: National Institute for Health and Care Excellence (NICE); 2015.

15. Prevention and management of postpartum haemorrhage (green-top guideline No. 52). London: Royal College of Obstetricians and Gynaecologists; 2016.

16. Blood transfusions in obstetrics (green-top guideline No. 47). London: Royal College of Obstetricians and Gynaecologists; 2015.

17. Stoltzfus R, Dreyfuss M. Guidelines for the use of iron supplements to prevent and treat iron deficiency anaemia. International Nutritional Anaemia Consultative Group (INACG). Washington (DC): ILSI Press; 1998 (www.who.int/nutrition/publications/mip cronutrients/guidelines_for_Iron_supplementation.pdf, accessed 11 April 2020).

18. Milman N. Postpartum anaemia I: definition, prevalence, causes, and consequences. Ann Hematol. 2011;90(11):1247-53. https:// doi.org/10.1007/s00277-011-1279-Z

19. Thromboembolic disease in pregnancy and the puerperium: acute management (green-top guideline No. 37b). London: Royal College of Obstetricians and Gynaecologists; 2015.

20. Preterm birth. Geneva: World Health Organization; 2018 (https://www.who.int/news-room/fact-sheets/detail/preterm-birth, accessed 11 April 2020).

21. ICD-11 for mortality and morbidity statistics (ICD-11 MMS). Geneva: World Health Organization; 2018 (https://icd.who.int/ browse11/l-m/en\#/http\%3a\%2f\%2fid.who.int\%2ficd\%2fentity\%2f1950379483, accessed 11 April 2020).

22. Neonatal encephalopathy and neurologic outcome, second edition. Pediatrics. 2014;133(5):e1482-88. https://doi.org/10.1542/ peds.2014-0724 
23. Kim H, Sohn Y, Lim J, Kim E, Kwon J, Park Y, et al. Neonatal outcome after preterm delivery in HELLP syndrome. Yonsei Med J. 2006;47(3):393-8. https://doi.org/10.3349/ymj.2006.47.3.393

24. Hermansen C, Mahajan A .Newborn respiratory distress. Am Fam Physician. 2015;92(11):994-1002.

25. Sankar MJ, Agarwal R, Deorari AK, Paul VK. Sepsis in the newborn. Indian J Pediatr. 2008; 75(3):261-6. 10.1007/s12098-008-0056-Z

26. Aleixandre-Benavent R, Simon C, Fauser BC. Trends in clinical reproductive medicine research: 10 years of growth. Fertil Steril. 2015;104(1):131-7. https://doi.org/10.1016/j.fertnstert.2015.03.025

27. Butler P, Khanna J. Assisted reproduction in developing countries - facing up to the issues. Prog Hum Reprod Res. $2003 ; 63: 1-8$.

28. Multiple gestation pregnancy. The ESHRE Capri Workshop Group. Hum Reprod. 2000;15(8):1856-64. https://doi.org/10.1093/ humrep/15.8.1856

29. Wang Y, Chughtai A, Farquhar C, Pollock W, Lui K, Sullivan E. Increased incidence of gestational hypertension and preeclampsia after assisted reproductive technology treatment. Fertil Steril. 2016;105(4):920-6. https://doi.org/10.1016/j.fertnstert.2015.12.024

30. Fitzsimmons B, Bebbington M, Fluker M. Perinatal and neonatal outcomes in multiple gestations: assisted reproduction versus spontaneous conception. Am J Obstet Gynecol. 1998;179(5):1162-7. https://doi.org/10.1016/s0002-9378(98)70125-5

31. Caserta D, Bordi G, Stegagno M, Filippini F, Podagrosi M, Roselli D, et al. Maternal and perinatal outcomes in spontaneous versus assisted conception twin pregnancies. Eur J Obstet Gynecol Reprod Biol. 2014;174:64-9. https://doi.org/10.1016/j. ejogrb.2013.12.011

32. Yang H, Choi YS, Nam KH, Kwon JY, Park YW, Kim YH. Obstetric and perinatal outcomes of dichorionic twin pregnancies according to methods of conception: spontaneous versus in vitro fertilization. Twin Res Hum Genet. 2011;14:98-103. https://doi. org/10.1375/twin.14.1.98

33. Moini A, Shiva M, Arabipoor A, Hosseini R, Chehrazi M, Sadeghi M. Obstetric and neonatal outcomes of twin pregnancies conceived by assisted reproductive technology compared with twin pregnancies conceived spontaneously: a prospective follow-up study. Eur J Obstet Gynecol Reprod Biol. 2012;165(1):29-32. https://doi.org/10.1016/j.ejogrb.2012.07.008

34. Daniel Y, OchshornY, Fait G, Geva E, Bar-Am A, Lessing B. Analysis of 104 twin pregnancies conceived with assisted reproductive technologies and 193 spontaneously conceived twin pregnancies. Fertil Steril. 2000;74(4):683-9. https://doi.org/10.1016/soo150282(00)01491-6 